


\title{
BRAZILIAN CLINOHUMITES: A NEW RECORD OF "PAN-AFRICAN/BRASILIANO HUMITE-EPOCH” IN GONDWANALAND
}

\author{
CLINOHUMITAS BRASILEIRAS: UM NOVO REGISTRO \\ DA “ÉPOCA PAN-AFRICANA/BRASILIANA \\ DA HUMIT” NO GONDWANA
}

A. O. Chaves ${ }^{1} \&$ M. L. S. Fernandes ${ }^{1}$

\begin{abstract}
Occurrences of humite-bearing marbles in the Kerala Khondalite Belt of southernmost India, South Madagascar, Sri Lanka, and the Lutzow-Holm Complex of East Antarctica prompt a fit of these areas with the Tanzania-Mozambique region of Africa and suggest an intercontinental 'humite-epoch' in Gondwanaland coeval with the waning stages of Pan-African tectonothermal activity. Far from these humite-bearing marbles, orange clinohumites are preserved in Brasiliano marbles from Itaoca/Gironda area (ES-Brazil). Such observation leads to the fact that Pan-African/Brasiliano Orogeny was not just one of increasing charnockite and granite genesis, but one also of concomitant intense fluorinated, water-rich fluid activity, which was transcontinental through Gondwanaland in its scope. Taken together, humite-bearing marbles from Pan-African/Brasiliano belts from Gondwanaland keep the huge dimensions of the halogenated hydrothermal fluid activity around such 'humite-epoch'.
\end{abstract}

Keywords - Clinohumite; Pan-African/Brasiliano; Gondwana

Resumo - Mármores com o raro mineral humita ocorrem no Cinturão de Kerala Khondalite na India Meridional, a sul de Madagascar, no Sri Lanka e no Complexo Lutzow-Holm da Antártida Oriental. Tais ocorrências permitem um ajuste dessas áreas com a região de Tanzânial Moçambique na África e sugerem uma "época da humita", de expressáo intercontinental no Gondwana, contemporânea aos estágios finais da atividade tectonotermal Pan-Africana. Bem distantes destes humita-mármores, clinohumitas de tons laranja encontram-se preservadas nos mármores Brasilianos da regiāo de Itaoca/Gironda (ES-Brasil). Tal observação leva ao fato de

\footnotetext{
1 Manoel Teixeira da Costa Research Center (CPMTC), Institute of Geosciences, Federal University of Minas Gerais (IGC-UFMG) - Brazil; alochaves@yahoo.com.br; fernandes.mlourdes@gmail.com
} 
que a Orogênese Brasiliano/Pan-Africana foi responsável não apenas pela gênese de granitos e charnockitos, mas também por concomitante intensa atividade de fluidos ricos em flúor e água. Esta atividade foi de caráter transcontinental por todo o Gondwana no seu âmbito. Em conjunto, os humita-mármores dos Cinturöes Pan-Africanos/Brasilianos do Gondwana guardam as assombrosas dimensöes da atividade dos fluidos hidrotermais halogenados relacionados à referida "época da humita".

\section{Palavras-chave-Clinohumita; Pan-Africano/Brasiliano; Gondwana}

\section{1 - Introduction}

The humites are a polysomatic series of extremely rare yellow to dark orange nesosilicates with the ideal formula $\mathrm{n}\left(\mathrm{Mg}_{2} \mathrm{SiO}_{4}\right) . \mathrm{Mg}(\mathrm{OH}, \mathrm{F})_{2}$ where $\mathrm{n}=1$ for norbergite; 2 for chondrodite; 3 for humite and 4 for clinohumite (ROBINSON et al., 1973). These minerals form only under high partial pressure of fluorine, in the presence of water-rich fluids (YOUNG \& MORRISON, 1992).

After PRADEEPKUMAR \& KRISHNANATH (2000), occurrences of humite-bearing marbles in the Kerala Khondalite Belt of southernmost India, South Madagascar, Sri Lanka, and the Lutzow-Holm Complex of East Antarctica prompt a fit of these areas with the Tanzania-Mozambique region of Africa and suggest an intercontinental 'humite-epoch' in Gondwanaland coeval with the waning stages of Pan-African tectonothermal activity (Fig. 1).

Far from these humite-bearing marbles, this manuscript aims to present the Brazilian record of Pan-African/Brasiliano 'humite-epoch' in Gondwanaland, more exactly the exotic orange mineral found in the Itaoca-Gironda marbles from Espírito Santo State (Brazil), and the geological significance of such occurrence.

\section{2 - Geological setting}

The Itaoca-Gironda terrains belong to the Mantiqueira Tectonic Province. According to VALERIANO et al. (2011), the Mantiqueira Province is a $3000 \mathrm{~km}$-long orogen that extends in roughly a NE-SW direction along the Atlantic coast of southeast-Brazil and Uruguay as a result of the the "Brasiliano"-Pan African convergence and eventual collision of paleocontinental ("cratonic") blocks during the Neoproterozoic to Cambrian times (650 - $490 \mathrm{Ma}$ ), leading to the amalgamation of the West-Gondwana supercontinent.

The Araçuaí/Ribeira Belt makes up the northern portion of the Mantiqueira Province (Fig. 2), which is part of Western Gondwana and continues in Africa as the West-Congo belt. A complex collision between the São Francisco Craton, now in Brazil, and the Congo/ Angolan Craton, now in Africa, drove the evolution of this belt (PEDROSA-SOARES \& WIEDEMANN-LEONARDOS, 2000).

The post-Transamazonian supracrustal rock sequence in the Araçuaí-Ribeira Belt has being attributed to the Paraíba do Sul Complex, which is marked by the presence of abundant banded gneisses, partially migmatized, metamorphosed in the amphibolite to granulite facies transition. It represents sedimentary marine sequences formed in two marine environments: a proximal environment, probably a shallow shelf which received terrigenous siliciclastic material to produce common sandy rocks (graywacke gneisses and 
sillimanite-quartzite) interlayered with thick carbonate layers; and a distal pelite-rich environment with minor carbonate intercalations. Distal pelites gave rise to extensive kinzigitic gneisses with thin calc-silicate lenses (PEDROSA-SOARES \& WIEDEMANN-LEONARDOS, 2000). Small igneous intrusions, consisting of metamorphosed gabbro, pyroxenite, diorite and biotite-andesine granitoids are also found in these terrains. The ages of $2104 \mathrm{Ma}, 774 \mathrm{Ma}$ up to $63119 \mathrm{Ma}$, obtained by U-Pb SHRIMP determinations on detritic zircon from this unit, were interpreted as the maximum and minimum source ages for the sediments (NOCE et al., 2004).

In this context, Itaoca-Gironda marbles are found as a subvertical NE-SW lens, 10 $\mathrm{km}$ in length, together to NE-SW lineament associated sheared rocks, which are related to the $550 \mathrm{Ma}$ Pan-African/Brasiliano orogeny. TUPINAMBÁ et al. (2007) described them as white marbles, containing calcite and dolomite, with granoblastic texture and showing incipient foliation. These rocks present decimetric dark layers containing silicate minerals that constitutes the subject of the present paper. JORDT-EVANGELISTA \& VIANA (2000) recognized, by optical means, the following mineral associations in the calc silicate rocks: olivine + clinohumite, spinel s.s. + magnesium-hornblende \pm phlogopite, diopside + calcic amphibole \pm plagioclase, biotite/phlogopite + plagioclase \pm quartz \pm calcic amphibole. The presence of spinel permitted them to conclude that the granulite metamorphism conditions were attained. The chlorite formation from spinel and phlogopite; tremolite from olivine and diopside; plagioclase saussuritization and sericitization indicate retrograde metamorphism.
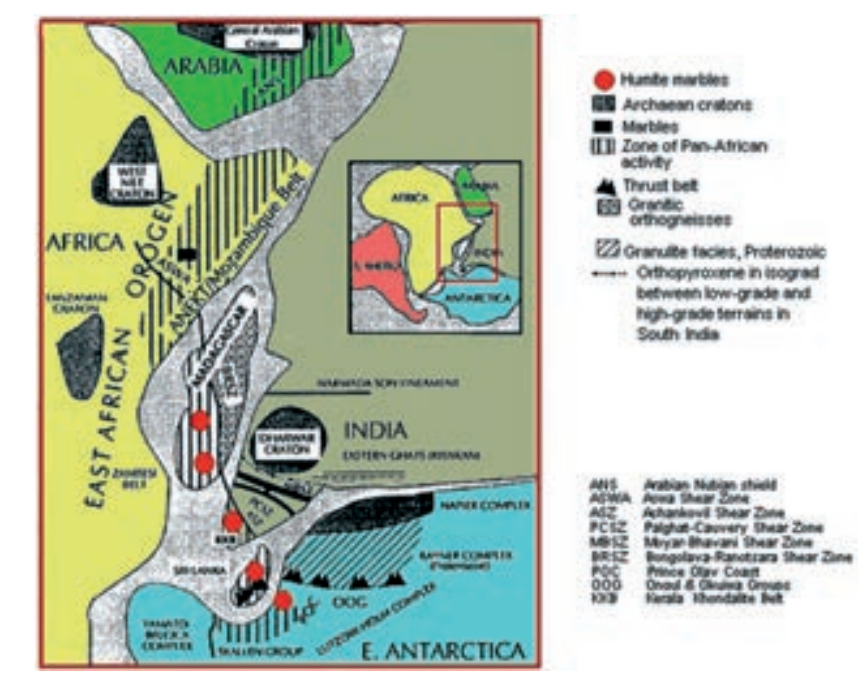
zation in

Fig. 1 - Neoproterozoic Gondwana geometry based on the perceived continuity of the Achankovil Shear Zone (ASZ), Bongolava-Ranotsara Shear Zone (BRSZ) and ASWA shear zone and humite-bearing marbles in East Gondwana. The East Gondwana-wide humite-epoch led to the formation of humite-bearing marbles in the Lutzow-Holm Complex, East Antarctica - Sri Lanka - Kerala Khondalite Belt (KKB), south India and south Madagascar. These are juxtaposed with the Tanzania-Mozambique region of the East African Orogen. The Pan-African ANEKT/Mozambique Belt starts in the Arabian Nubian Shield (ANS) and swings east near the Tanzanian craton, follows the trend of the BRSZ, the ASZ, covers Sri Lanka and culminates in the Lutzow-Holm complex (LHC) of East Antarctica (modified from PRADEEPKUMAR \& KRISHNANATH, 2000). 


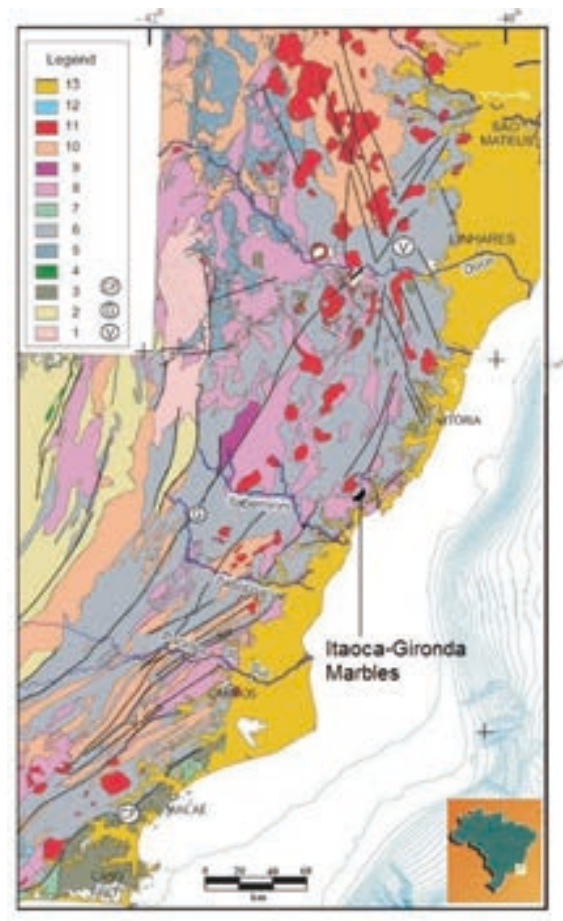

Fig. 2 - Simplified geological map of the northern Mantiqueira Tectonic Province (Araçuaí/Ribeira Orogen) from southeast Brazil. Legend: 1 - Archean. Paleoproterozoic: 2 - Paleoproterozoic unit of Occidental terrain, 3 - Regiáo dos Lagos Complex. Neoproterozoic: 4 - metaultramafic rocks, 5 - Rio Doce Gr., 6 - Kinzigitic Complex, 7 - Buzios and Palmital units, 8 - Pre-collisional suites, mainly granites to granodiorites; 9 - Undifferenciated charnockitoids, 10 - Syn-collisional suites, mainly leucogranites; 11 - Late-to-post-collisional suites; 12 - Cenozoic alkaline intrusions, 13 - Neogene

(Barreiras Gr. and Quaternary deposits). CF: Cabo Frio tectonic boundary; G: Guaçuí fault; V: Vitoria-Colatina shear zone. Modified from FONTANELLI et al. (2009).

\section{3 - Methodology and results}

Field work has been done at Itaoca-Gironda in order to collect regional white marble samples, but only those with orange mineral macroscopic incrustations or veins. This material has been submitted to hydrocloric acid attack to eliminate carbonates and to concentrate non-carbonate material, including the orange mineral. After that, X-ray diffraction has been done in powder of the mineral phases previously separated by their color. The X-ray diffractometer system used was PANALYTICAL XPERT-PRO (generator settings: $45 \mathrm{~mA}$ and $40 \mathrm{kV}$ ) and analytical operating conditions followed step size $0.00502 \mathrm{Th}$ and scan step time 0.8000 s. Besides calcite and dolomite from marble, forsterite, spinel, serpentine (antigorite), talc, diopside, tremolite, clinochlore, pyrite, and apatite have been found. Orange mineral concentrate yielded the diffractogram shown in Fig. 3, which reveals the presence of exotic clinohumite/titanoclinohumite in such mineral association. Enlarged pictures of Itaoca-Gironda clinohumites are presented in figure 4. 


\section{4 - Discussions and conclusions}

The similarities between geological/mineralogical features of marbles from East African Orogen, South Madagascar, South India, Sri Lanka, East Antarctica described by PRADEEPKUMAR \& KRISHNANATH (2000) and Araçuaí/Ribeira Orogen of southeast Brazil are remarkable. In almost all regions, marbles are related to shear zones and associated to high grade metasedimentary rocks and granitoids. Such rocks were formed during Pan-African/Brasiliano Orogeny.

Marble mineralogy is practically the same in all regions, represented by calcite and dolomite, forsterite, spinel, serpentine (antigorite), talc, diopside, tremolite, clinochlore, pyrite, apatite and humite-group minerals. Is evident the significance of magnesium and calcium in such mineral association. Calcite, dolomite, forsterite, spinel, diopside, pyrite and apatite possibly have been formed/recrystallized during granulite facies prograde metamorphism. Serpentine, talc, tremolite, clinochlore and clinohumite probably have been formed from forsterite during amphibolite facies retrograde metamorphism, when fluorinated, water-rich fluid activity was present.

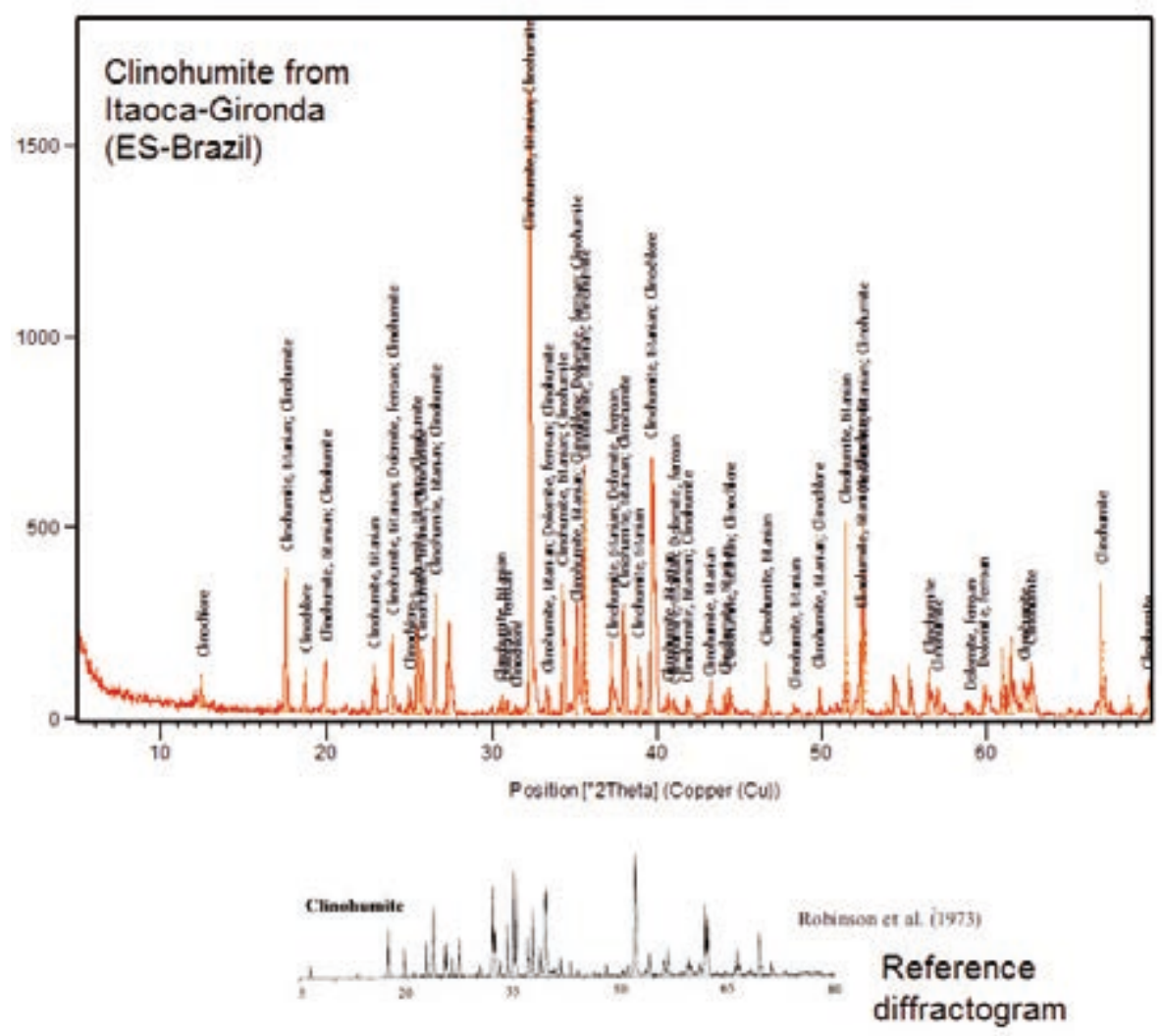

Fig. 3 - X-ray diffractogram showing the presence of clinohumite in Itaoca-Gironda marble samples. 

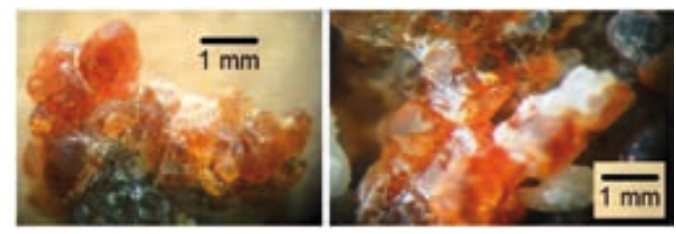

Fig. 4 - Clinohumites from Itaoca-Gironda (ES-Brazil).

It is more important to highlight that, far from humite-bearing marbles presented in Fig. 1, orange clinohumites are preserved in Brasiliano marbles from Itaoca/Gironda area. Such observation lead to the fact that Pan-African/Brasiliano Orogeny was not just one of increasing charnockite and granite genesis, but one also of concomitant intense fluorinated, water-rich fluid activity, which was transcontinental through Gondwanaland in its scope (PRADEEPKUMAR \& KRISHNANATH, 2000) (Fig. 5). Taken together, humite-bearing marbles from Araçuaí/Ribeira and Mozambique Belts keep the huge dimensions of the Pan-African/Brasiliano halogenated hydrothermal fluid activity.

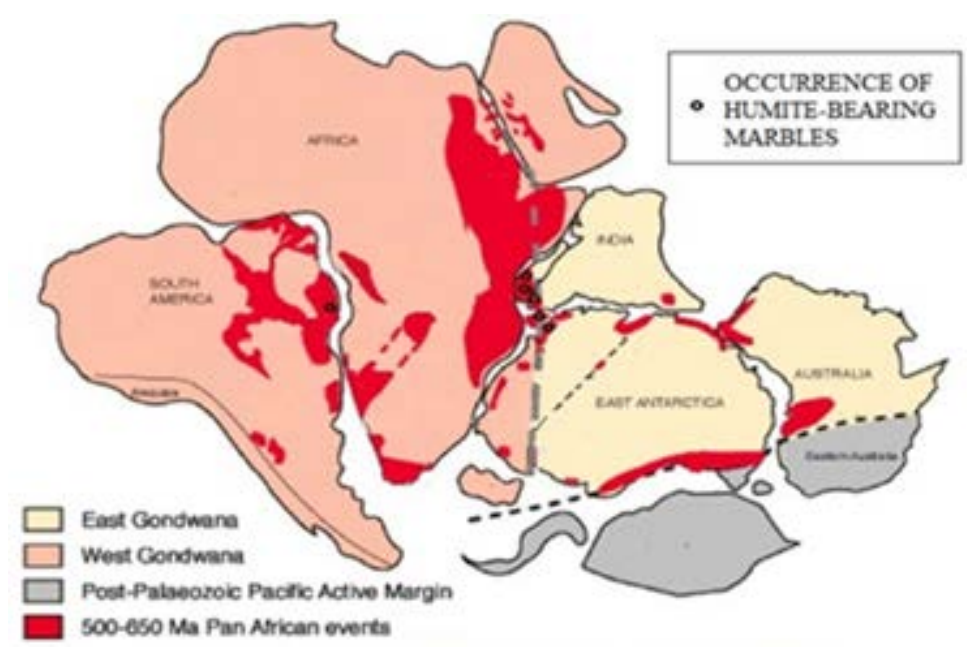

Fig. 5 - Gondwana assembly reconstruction showing location of Pan-African/Brasiliano events and occurrence of humite bearing marbles (adapted from GRUNOW, 1995 and PRADEEPKUMAR \& KRISHNANATH, 2000).

\section{References}

FONTANELLI P. R., De ROS L. F. \& REMUS M. V. D. (2009) - Provenance of turbiditic reservoir sandstones from the Jubarte Oilfield, Campos Basin, Eastern Brazilian Margin. Marine Petroleum Geology, 26, p. 1274-1298. 
GRUNOW, A. M. (1995) - Implications for Gondwana of new Ordovician palaeomagnetic results from igneous rocks in the southern Victoria Land, Antarctica. Journal of Geophisical Research, 100: 12589-12603.

JORDT-EVANGELISTA, H. \& VIANA, D. J. (2000) - Mármores da região de Itaoca (es) e escarnitos no contato com diques máficos e félsicos: mineralogia e petrogênese. Geonomos, 8, p. 61-67.

NOCE, C. M., PEDrOSA-SOARES, A. C., De CAMPOS, C. M. \& MEDEIROS, S. R. (2004) - Idades U-Pb (SHRIMP) de zircôes detríticos do Complexo Kinzigítico do norte do Espírito Santo: evidência de sedimentação em bacia de retroarco do Orógeno Araçuaí. In: 42o Congresso Brasileiro de Geologia, Araxá, Anais, p. 187.

PEDROSA-SOARES, A. C. \& WIEDEMANN-LEONARDOS, C. M. (2000) - Evolution of the Araçuaí Belt and its conection to the Araçuaí-Ribeira Belt, eastern Brazil. In: Cordani, U.G., Milani, E.J., Thomaz Filho, A. and Campos, D.A. (Editors), Tectonic Evolution of South America, 31st IGC, p. 265-285.

PRADEEPKUMAR A. P. \& KRISHNANATH R. (2000) - A Pan-African 'Humite Epoch' in East Gondwana: implications for Neoproterozoic Gondwana geometry. Journal of Geodynamics, 29, p. 43-62.

ROBINSON K, GIBBS G. V. \& RIBBE, P. H. (1973) - The crystal structures of the humite minerals. IV clinohumite and titanoclinohumite. American Mineralogist, 58, p. 43-49.

TUPinAmbÁ, M., HEILBRON, M., DUARTE, B. P., NOGUEIRA, J. R., VALLADARES, C., ALMEIDA, J., SILVA, L. G. do E., MEDEIROS, S. R. de, ALMEIDA, C. G. de, MIRANDA, A., RAGATKY, C. D., MENDES, J. \& LUDKA, I. (2007) - Geologia da Faixa Ribeira setentrional: estado da arte e conexóes com a Faixa Araçuaí. Geonomos, 15, p. $67-79$.

VAlERIANO, C. de M., TUPinAmBÁ, M., SimONETTI, A., HEILBRON, M., ALMEIDA, J. C. H. de, \& EIRADO, L. G. do. (2011) - U-Pb LA-MC-ICPMS geochronology of Cambro-Ordovician post-collisional granites of the Ribeira belt, southeast Brazil: Terminal Brasiliano magmatism in central Gondwana supercontinent. Journal of South American Earth Sciences 32, p. 416-428.

YOUNG, E. D. \& MORRISON, J. (1992) - Relation among net-transfer reaction progress, ${ }^{18} \mathrm{O}-{ }^{13} \mathrm{C}$ depletion, and fluid infiltration in a clinohumite-bearing marble. Contributions to Mineralogy and Petrology, 111, p. 391-408. 